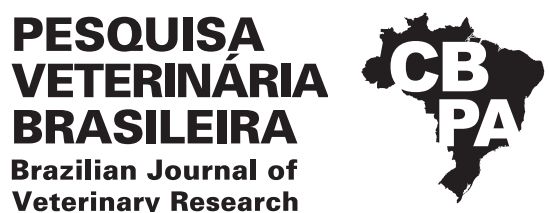

\title{
Seasonal variations of male reproductive parameters of Tomodon dorsatus from Southeastern Brazil ${ }^{1}$
}

\author{
Luciane Lily Abud ${ }^{2}$ and Bruno Cesar Schimming $2,3 *$ (D)
}

\begin{abstract}
Abud L.L. \& Schimming B.C. 2021. Seasonal variations of male reproductive parameters of Tomodon dorsatus from Southeastern Brazil. Pesquisa Veterinária Brasileira 41:e06725, 2021. Laboratório de Anatomia de Animais Selvagens, Universidade Estadual Paulista "Júlio de Mesquita Filho", Cx. Postal 510, Botucatu, SP 18618-970, Brazil. E-mail: bruno.schimming@unesp.br

The morphology of the male reproductive tract of Tomodon dorsatus was described in the austral seasons of the year considering macroscopic and microscopic variables. For this purpose, 56 specimens from the herpetological collection of the "Instituto Butantan" were used. Fragments of the testes, kidneys and ductus deferens were collected and submitted to histological routine. The peak of the testicular volume was observed in the summer and the epithelium of the seminiferous tubules had higher height in the summer $(p=0.001)$. The testes were active throughout the year, however, the spermiogenesis peaked in the summer. There were spermatozoa in the lumen of the ductus deferens in all seasons of the year. Renal length was higher in autumn ( $p=0.027)$, and renal width did not show a significant increase $(p=0.237)$. The diameter and epithelial height of the sexual segment of the kidney (SSK) showed hypertrophy in winter and spring, coinciding with the mating period. Based on findings of this study, we can suggest that, at the population level, the reproductive cycle of T. dorsatus can be considered seasonal semi-synchronous, due to the peak of spermiogenic activity in the hot season, and discontinuous at the individual level.
\end{abstract}

INDEX TERMS: Reproduction, Tomodon dorsatus, Brazil, snake, sexual segment, kidney, testis, wildlife animals.

RESUMO.- [Variações sazonais dos parâmetros reprodutivos do macho de Tomodon dorsatus do sudeste brasileiro.] A morfologia do trato reprodutivo do macho de Tomodon dorsatus foi descrita nas estações climáticas do ano com base em variáveis macroscópicas e microscópicas. Para isto, foram usados 56 espécimes oriundos da coleção herpetológica do Instituto Butantan. Fragmentos dos testículos, rins e ductos deferentes foram coletados e submetidos à rotina histológica. 0 volume testicular foi maior no verão e o epitélio dos túbulos seminíferos mostrou uma maior altura no verão $(p=0.001)$. Os testículos estavam ativos durante todo o ano, contudo, a espermiogênese foi maior no verão. Espermatozoides foram encontrados no lúmen do ducto deferente em todas as estações do ano. 0 comprimento renal foi maior no outono ( $p=0.027)$, e a largura renal não mostrou um aumento significativo ( $p=0.237)$. 0 diâmetro e a altura epitelial do segmento sexual

\footnotetext{
${ }^{1}$ Received on November 1, 2020.

Accepted for publication on December 29, 2020.

${ }^{2}$ Graduate Program in Wild Animals, Faculdade de Medicina Veterinária e Zootecnia, Universidade Estadual Paulista “Júlio de Mesquita Fiho" (Unesp), Botucatu, SP 18618-681, Brazil.

${ }^{3}$ Laboratório de Anatomia de Animais Selvagens, Universidade Estadual Paulista "Júlio de Mesquita Fiho" (Unesp), Cx. Postal 510, Botucatu, SP 18618-970, Brazil. *Corresponding author: bruno.schimming@unesp.br
}

do rim (SSR) mostrou hipertrofia nas estações inverno e primavera, coincidindo com o período reprodutivo. Com base nestes resultados, pode-se sugerir que, em nível populacional, o ciclo reprodutivo de $T$. dorsatus possa ser considerado semi-sincrônico sazonal, devido à atividade espermiogênica na estação quente, e descontínuo em nível individual.

TERMOS DE INDEXAÇÃO: Reprodução, Tomodon dorsatus, serpentes, segmento sexual, rim, testículo, animais selvagens.

\section{INTRODUCTION}

The Tomodon dorsatus Duméril, Bribon, and Duméril, 1854 is a neotropical snake that belongs to the Dipsadidade family (Costa \& Bérnils 2015). This dipsadid snake occurs along the Atlantic Forest and is widely distributed in South America, including Brazil, Paraguay, Uruguay and Argentina (Bizerra 1998, Foesten et al. 2017). They are snakes predominantly terrestrial with a diurnal activity pattern (Bizerra 1998, Bizerra et al. 2005, Citadini \& Navas 2013). Their feeding behaviour is specialized for being strictly malacophagous, feeding mainly on slugs (Bizerra 1998). Bizerra et al. (2005) reported that diet of T. dorsatus consisted exclusively on veronicellid slugs, mostly Sarasinula spp. Sexual dimorphism can be evident in 
T. dorsatus in which females have larger body size and have larger heads than males (Bizerra et al. 2005, Loebens et al. 2019). This head sexual dimorphism can be related with the prey size on what females may be able to consume larger preys than conspecific males (Loebens et al. 2019). Therefore, the T. dorsatus males presented higher locomotor performance and higher aerobic resting metabolic rate than females, and this may be related to its aggressiveness and reproductive success (Santos 2019). This snake is viviparous with seasonal biennial reproductive cycle (Bizerra et al. 2005, Loebens et al. 2019, 2020).

The study of reproductive biology comprises several biological factors, such as ecology, behavioral aspects, physiology, evolution and anatomy. In addition, the histological analysis of the gonadal tissue for the verification of cellular processes such as gametogenesis is essential for the determination of a reproductive cycle (Rojas et al. 2013, Almeida-Santos et al. 2014, Loebens et al. 2017). Loebens et al. (2020) claimed that the combined morpho-anatomical and histological analyses allowed to precisely describe the reproductive cycle in males and females. According to Tsai \& Tu (2000), the studies of the reproductive features of tropical and subtropical snakes were limited. However, in the last decades, the analysis of aspects of the reproductive biology of neotropical snakes has been increasing, mainly with the research of specimens deposited in the collections (Girons 1982, Pizzato et al. 2008, Mathies 2011, Rojas et al. 2013, Almeida-Santos et al. 2014, Loebens et al. 2017). Girons (1982) and Schuett (1992) categorized the cycles of males considering the temporal occurrence of spermatogenesis, the sperm storage phase, mating period, and the austral seasons. Mathies (2011) classified the reproductive cycle of male tropical snakes into three categories: discontinuous cyclic, when a reproductive rest phase of the gonads occurs for some period of the year; cyclic, where the gonads are not completely inactive, but have a reduced activity; and acyclic, when the gonads have constant activity throughout the year.

There are a few studies concerning the reproductive features in the T. dorsatus. The natural history and reproductive strategies of T. dorsatus were reported by Bizerra (1998) and Bizerra et al. (2005). These authors presented a macroscopical study about reproductive cycle of this snake and claimed that this snake presents a post-nuptial reproductive cycle, that is, the production of the gametes occurs after copulation, occurring sperm storage in the ductus deferens until the next copulation (Bizerra 1998, Bizerra et al. 2005). The reproductive biology of T. dorsatus males and females from the south region of Brazil was studied based on morpho-anatomical and histological features (Loebens et al. 2020). To these authors, this snake has a seasonal pattern of reproduction, with a strong peak in spring. Therefore, males and females have evolved to develop sperm storage strategies. The sperm storage could be observed in the ductus deferens and utero-vaginal junction, respectively, in males and females (Loebens et al. 2020).

The reproductive strategies can be influenced by many correlated factors, such as geographic and environmental conditions (Brown \& Shine 2006, Loebens et al. 2020). Thus, this study aimed to evaluate the morphological activity of T. dorsatus males in southeastern Brazil throughout the austral seasons, through morpho-anatomical and histological analyses, in order to contribute to the reproductive biology of this species, since the environmental conditions as well as the climate found in this region can differ from that found in other Brazilian regions. In addition, the morphological and histological analyzes of the reproductive system of T. dorsatus provide an experimental model to study the reproductive cycle in neotropical snakes.

\section{MATERIALS AND METHODS}

Animals. Fifty-six Tomodon dorsatus males and adults were used in this study. All specimens used were received by "Instituto Butantan", São Paulo, Brazil and were obtained from São Paulo municipality and surroundings areas situated in the Atlantic Forest and rural areas. Fifty snakes belong to the Herpetological Collection "Alphonse Richard Hoge" and were deposited from 2010 to 2017. Six live animals received at the time of this study by the Butantan Institute were also analysed. The date that "Instituto Butantan" has received the snakes was used as reference to determine the austral seasons of the year: summer (late December-late March), autumn (late March-late June), winter (late June-late September) and spring (late September-late December). Live snakes were euthanized with an intracelomatic injection of thionembutal $(30 \mathrm{mg} / \mathrm{kg})$ followed by an intracardiac injection of $0.2 \mathrm{ml}$ of potassium chloride (Rojas 2009). This study was approved by the Ethical Committee for Animal Research of the "Faculdade de Medicina Veterinária e Zootecnia", "Universidade Estadual Paulista 'Júlio de Mesquita Fiho', (CEUAFMVZ, Unesp, no. 937-2017).

For each snake, were obtained information concerning month of death. The testicular volume was calculated using the formula $\mathrm{TV}=4 / 3$. П.a.b.c, where $\mathrm{a}=$ half of length, $\mathrm{b}=$ half of width and $\mathrm{c}=$ half of thickness (Pleguezuelos \& Feriche 1999, Barros et al. 2012). The data collected from the reproductive system were (1) width of distal portion of the duct deferens, and (2) length and width of the kidney to determine the hypertrophy of the sexual segment of the kidney (SSK). As a standard procedure, only organs of the right side were used in this study. All measurements were performed with Digimess ${ }^{\circledR}$ digital caliper.

Histological procedures. Fragments of the middle part of the testis, distal portion of ductus deferens, and cranial part of kidney, were collected for histological analysis $(n=31)$. Samples of the animals from the herpetological collection were fixed in $70 \%$ alcohol. The fragments of the animals recently euthanized were fixed in $10 \%$ formoldehyde solution for 24 hours and destined for histological routine with inclusion in Paraplast ${ }^{\mathrm{TM}}$ (Sigma, USA), slides of $5 \mu \mathrm{m}$ in thickness, and hematoxylin and eosin (HE) stains. The epithelial height and width of the seminiferous tubules, and the epithelial height and width of the sexual segment of the kidney (SSK) were measured. Ten measures of each variable per individual of the SSK and seminiferous tubules were obtained using the software LAS V3 (Leica), coupled in a Leica DMLB 500 microscope. In order to reduce the error, only circular forms in transverse sections of the testes and SSK were measured. The aspect of the ductus deferens either with or no spermatozoa in the tubular lumen, and the morphology of the epithelium of the seminiferous tubules were also used as a criterion for stablishing the reproductive activity of the snakes.

Classification of testicular epithelium. The testes were analyzed for the testicular phase and classified according to the criteria established by Tsai \& Tu (2000): stage I (early recrudescence): seminiferous tubules contained mainly spermatogonia, primary spermatocytes, some secondary spermatocytes and spermatids; Stage II (late recrudescence): spermatozoa start to appear; stage III (spermiogenesis): presence of large amounts of spermatozoa in the lumen, secondary spermatocytes and spermatids start to disappear; 
stage IV (early regression): the amount of spermatozoids decreased, spermatogonia and primary spermatocytes remained; stage V (late regression): no spermatozoids, one or two layers of spermatogonia and primary spermatocytes.

Statistical analysis. The data collected were compared between the several seasons of the year. Multiple comparisons were performed. The descriptive analysis of all variables was performed, such as the calculation of the mean, standard deviation and quartiles. Assumptions of normality were assessed via the Kolmogorov-Smirnov test. The significance level was set at $p<0.05$. In case of significant difference between seasons, were performed multiple comparisons of StudentNewman-Keuls. Analyzes were performed in SPSS Statistics 17.0 and in BioEstat 5.0.

\section{RESULTS}

\section{Morphometric analysis}

Testicular length in Tomodon dorsatus ranged from $10.71 \mathrm{~mm}$ to $31.03 \mathrm{~mm}$. No significant changes occurred in testicular volume in the different austral seasons $(p=0.416)$. However, the peak of the testicular volume was observed in the summer (Fig.1). The width of the distal portion of the ductus deferens ranged from 0.35 to $4.10 \mathrm{~mm}$. Although there was a difference in the diameter of the ductus deferens, there was no significant seasonal variation $(p=0.145)$. However, the width of the duct deferens peaked in winter (Fig.2). The renal length varied from 25.11 to $58.84 \mathrm{~mm}$, and the width was between 3.01 and $9.64 \mathrm{~mm}$. The renal length of T. dorsatus presented a significant variation ( $p=0.027)$, peaked in autumn and winter, however, no variation in width was observed during the different seasons ( $p=0.237$ ) (Fig.3).

Histological analysis of the testis showed that there was a significant difference in the width $(p=0.001)$ and in the epithelial height $(p=0.001)$ of the seminiferous tubules throughout the year. The seminiferous epithelium width was seasonal and it was larger in the summer and lower in the winter compared to other seasons. There was an increase in the height of the seminiferous epithelium in the summer, due to the multiplication of the germ cells responsible for spermatogenesis. The seminiferous epithelium height presented a lower increase in winter (Fig.4). Histological analysis showed

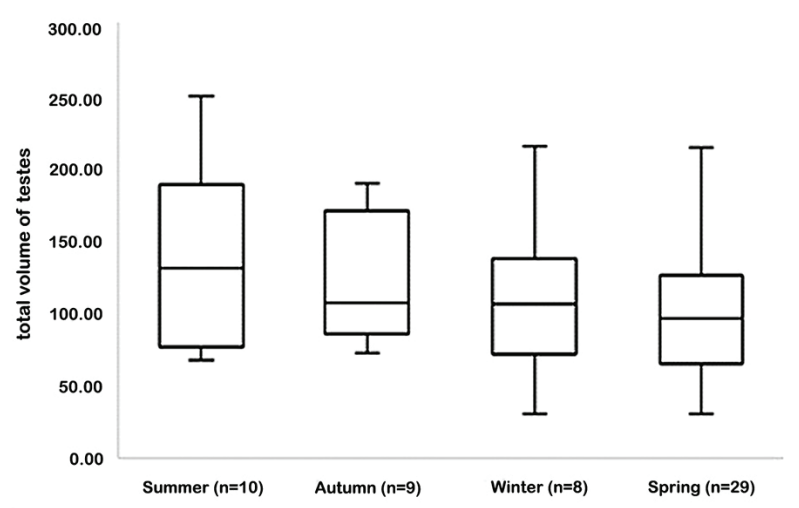

Fig.1. Relationship between the seasons of the year and the average of testicular volume $(p=0.416)$. Middle line represents average values, boxes show standard deviations and whiskers represent minimum and maximum values.

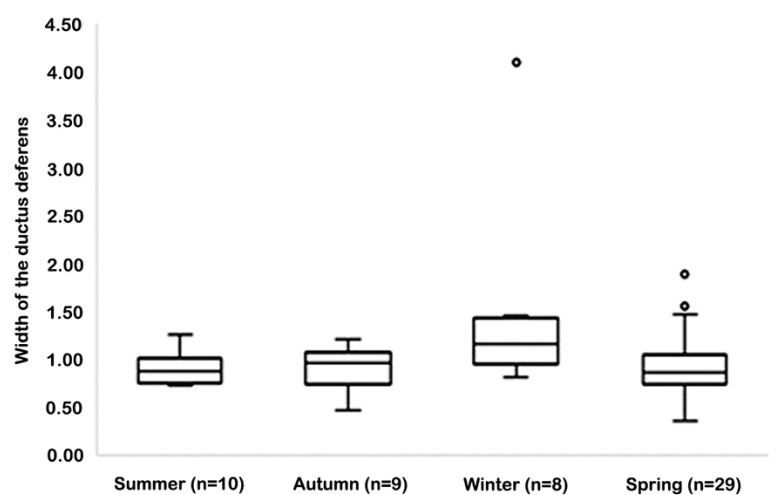

Fig.2. Relationship between the seasons of the year and average of ductus deferens width $(p=0.145)$. Middle line represents average values, boxes show standard deviations, whiskers represent minimum and maximum values, and dots indicate outliers.
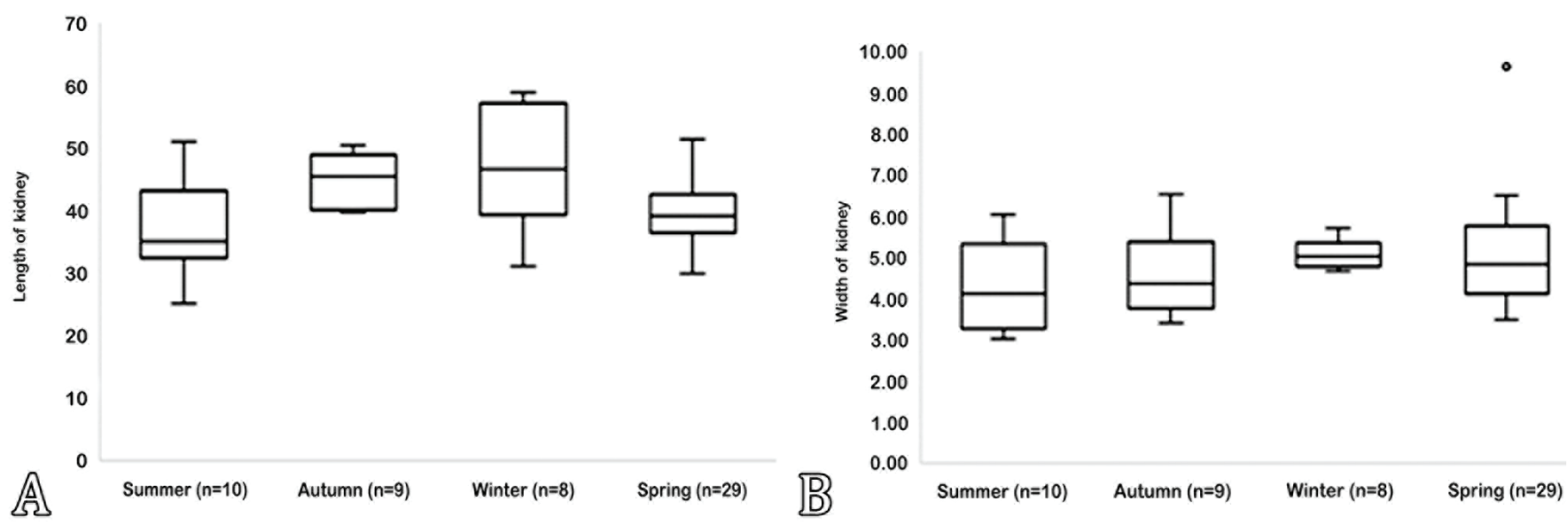

Fig.3. Relationship between the seasons of the year and the average of $(\mathbf{A})$ kidney length $(p=0.027)$ and $(\mathbf{B})$ width ( $p=0.237)$. Middle line represents average values, boxes show standard deviations whiskers represent minimum and maximum values, and dots indicate outliers. 
that SSK width presented significant differences between the season ( $p=0.001)$, with the highest difference between winter and summer ( $p=0.0001)$. There was no significant difference between winter and spring ( $p=0.113)$. The height of the SSK epithelium also showed a significant difference $(p=0.001)$, which differed between winter and summer $(p=0.0001)$. The peak of SSK was observed in the winter, although snakes with SSK activity could be observed throughout the year (Fig.5).

\section{Morphological analysis}

The T. dorsatus showed kidneys paired, elongated and lobulated. The right kidney was located cranially to the left kidney. The testes were elongated and the right testis was cranial to the left one. The ductus deferens presented a convoluted aspect due to the presence of spermatozoa (Fig.6).

Different testicular stages were found throughout the year. The early recrudescence (stage I) was observed in two periods of the year (winter and spring) and the late recrudescence (stage II) in summer, autumn and winter. Spermiogenesis (stage III) was found in all seasons of the year. Early testicular regression (stage IV) was found in autumn, winter and spring, and late testicular regression (stage $\mathrm{V}$ ) was observed in the winter and spring. However, some testicular stages were more marked in certain periods such as: spermiogenesis in the summer, where the individuals presented marked synchrony. In the autumn, the specimens were either in spermiogenesis or regression. In the winter, the testicular regression was well marked, and in spring, the absence of synchrony between the individuals was observed (Fig.7 and 8). Sperm was present throughout the year in the distal portion of the duct deferens in the T. dorsatus (Fig.9).

\section{DISCUSSION AND CONCLUSION}

Some snake species exhibited a testicular increase during the active phase of the gonads, which is an indicator of sperm
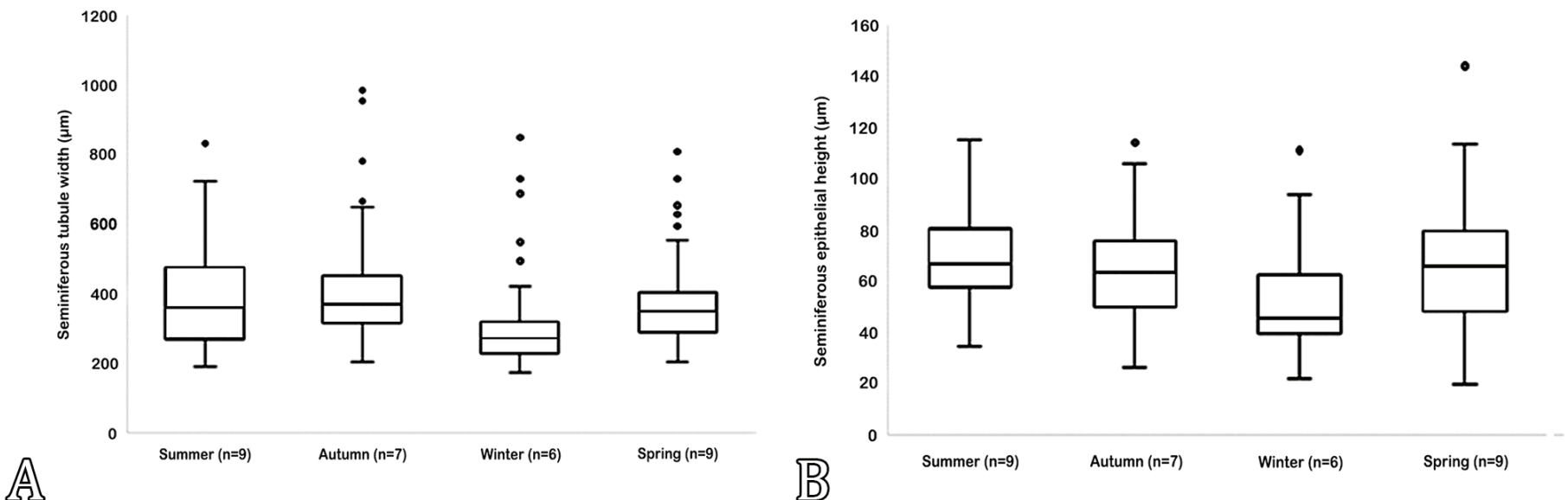

Fig.4. Relationship between the seasons of the year and the average of (A) seminiferous tubules width ( $p=0.001)$, and (B) seminiferous tubules height $(p=0.001)$. Middle line represents average values, boxes show standard deviations, whiskers represent minimum and maximum values, and dots indicate outliers.
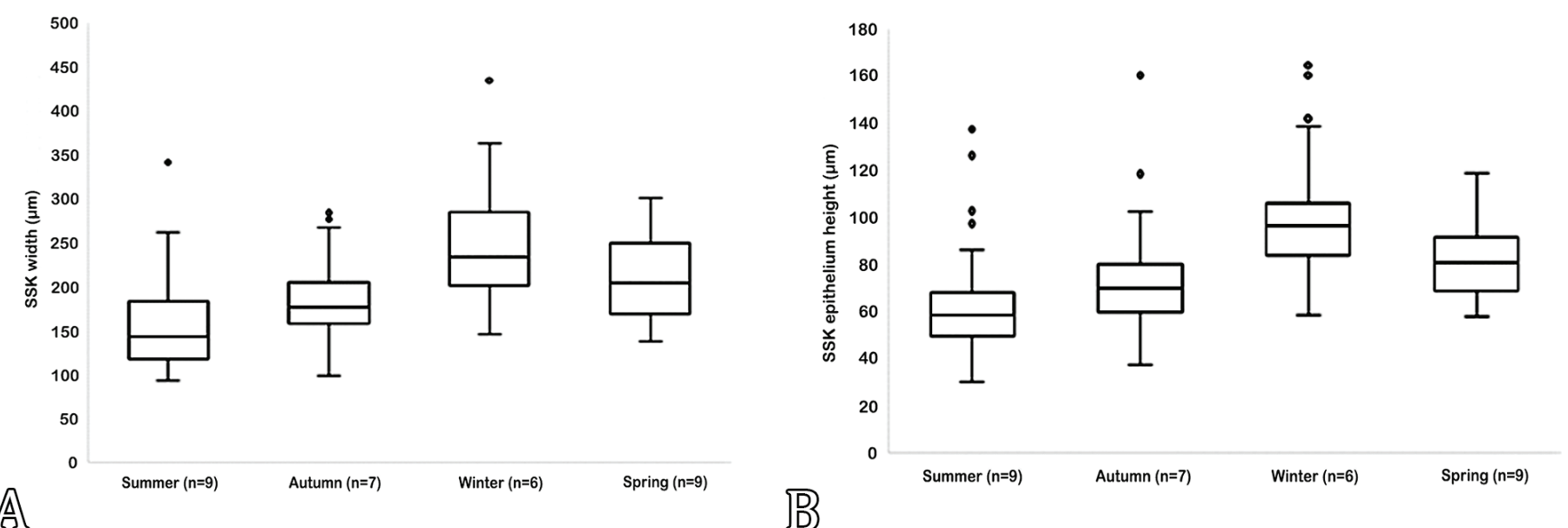

Fig.5. Relationship between the seasons of the year and the average of (A) sexual segment of the kidney (SSK) width ( $p=0.001)$ and (B) epithelial height of SSK ( $p=0.001)$. Middle line represents average values, boxes show standard deviations, whiskers represent minimum and maximum values, and dots indicate outliers. 
activity (Schuett 1992), although testes of snakes such as pit viper Crotalus scutulatus were larger during the regression phase (Schuett et al. 2002). The testicular volume of Tomodon dorsatus showed no significant changes in the austral seasons studied, although a peak in testicular volume occurred in the summer. Loebens et al. (2020) also recorded that the highest values of testicular volume in January (summer) in T. dorsatus from the south region of Brazil. The dipsadid Lygophis anomalus also showed a peak in testis volume in the summer season (Sivan et al. 2016). This absence of seasonal and no significant variation in the testicular volume may be indicative of a continuous reproductive cycle in these males (Loebens et al. 2020).

Therefore, the males of $T$. dorsatus presented significant variations in the width and height of the seminiferous epithelium throughout the year. The histological analyses performed in this study showed active seminiferous tubules in the different seasons of the year; however, the spermiogenesis was well marked in the summer. In the autumn most of the individuals are in spying or at the end of the reproductive season, that is, initiating regression; and in the winter, some individuals are in recrudescence or regression. In a previous study in the $T$. dorsatus, the diameter and epithelial height of seminiferous tubules varied seasonally and were larger in the summer.
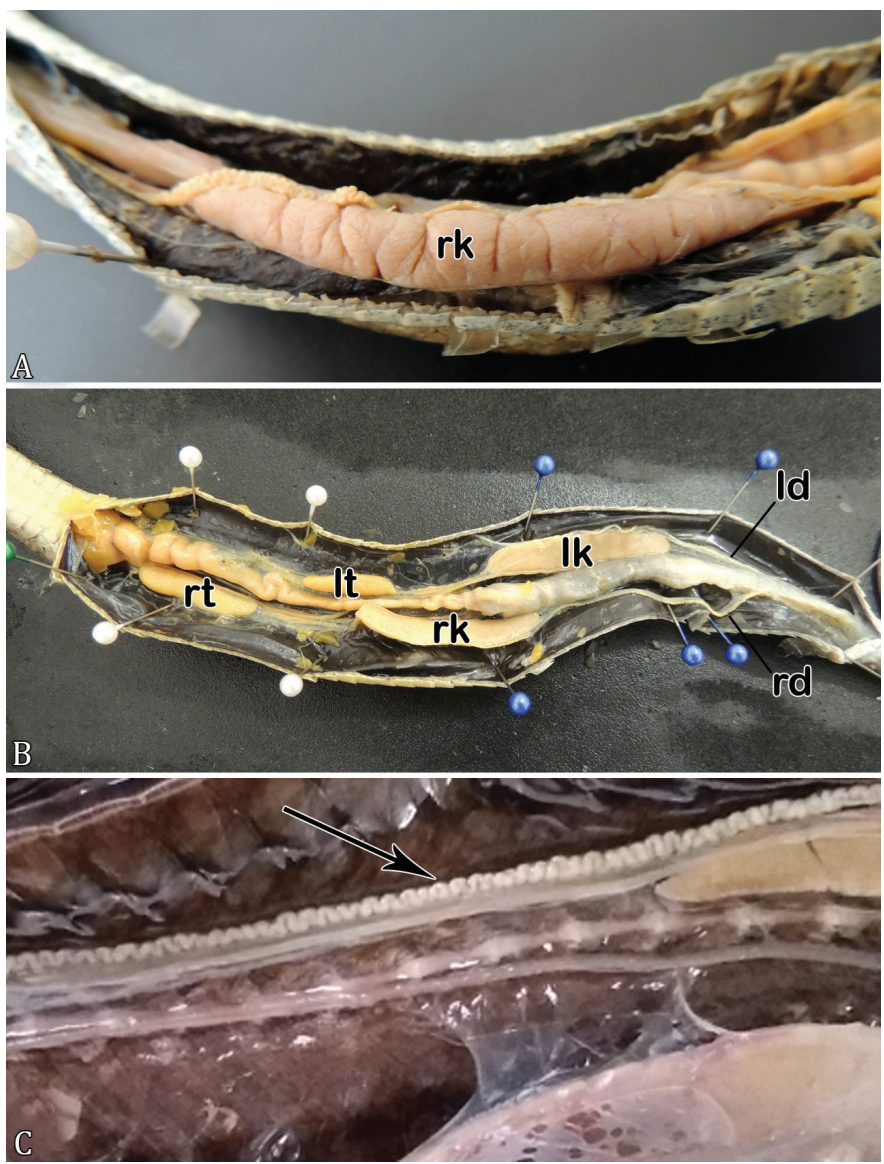

Fig.6. Ventral view of male Tomodon dorsatus body cavity. (A) Right kidney (rk). (B) Right testis (rt), left testis (lt), right kidney (rk), left kidney (lk), right ductus deferens (rd) and left ductus deferens (ld). (C) High magnification of the body cavity showing ductus deferens and its zig-zag appearance (arrow).
These snakes presented the highest activity (hypertrophy) of the testes during spring and summer, coinciding with the spermiogenesis stage (Loebens et al. 2020).

Despite the great testicular activity among the individuals, at the population level, the reproductive cycle of T. dorsatus can be considered seasonal semi-synchronous with a peak of spermiogenesis activity in the hot season, and discontinuous at the individual level based on Mathies (2011), similar to that reported for other neotropical snakes (Marques \& Sazima 2004, Rojas et al. 2013), and corroborating the studies carried out by Bizerra (1998) and Loebens et al. (2020). In this study, the spermiogenesis phase peaked in the hot season and early cold season, coinciding with the time when the females of $T$. dorsatus were vitellogenic and the period of mating (Bizerra et al. 2005).

Bizerra (1998) reported that T. dorsatus presented a postnuptial, dissociated or type I reproductive cycle according to the classification proposed by Girons (1982). This reproductive cycle was characterized by spermatogenesis occurred in the hot season, and sperm storage occurred in the cold season, however, although the spermatogenic activity peaked in summer, the testes were also active in other periods of the year, making it difficult to classify them in relation to copulation.

According to Rojas et al. (2013), after spermatozoa are produced in the testes, they pass through genital accessory ducts and are deposited in the ductus deferens, when the spermatozoa are stored. The increase in the diameter of the ductus deferens is indicative of reproductive activity since the sperms are stored in the ductus deferens (Sever et al. 2002, Stanley \& Sever 2011). In this study, it was possible to visualize spermatozoa in the ductus deferens in all seasons of the year showing the storage of spermatozoa in this species of snake. The diameter of the ductus deferens showed a peak in winter, although without a significant increase, which might suggest a spermiation process with posterior sperm storage. The ductus deferens of $T$. dorsatus presented a convoluted aspect due to the presence of spermatozoa throughout the year. Similar findings were reported to the dipsadid snakes such as Erythrolamprus poecilogyrus sublineatus (Quintela et al. 2017) and T. dorsatus from the south region of Brazil (Loebens et al. 2020). This feature is an evidence of a long-term sperm storage (Loebens et al. 2020). Aldridge et al. (2020) reported that in snakes, the ductus deferens is the major site for long-term sperm storage. This long-term storage increases reproductive success of males' snakes (Gribbins et al. 2005).

The sperm storage has been studied in females (Fox 1956, Schuett 1992, Almeida-Santos \& Orsi 2002, Loebens et al. 2017, 2020, Aldridge et al. 2020), however, this reproductive event is also present in males (Almeida-Santos et al. 2014). In addition to the sperm storage function, studies have shown a secretory action of the ductus deferens in viperids (Siegel et al. 2009). This secretory activity may be related to the storage of spermatozoa in the ductus deferens. The spermatozoa gain motility and improve their performance when are stored in the convoluted ductus deferens. Almeida-Santos et al. (2004) observed in Crotalus durissus terrificus that spermatozoa became more mobile as they moved from the proximal to the distal portions of the ductus deferens, suggesting that the internal environment along the genital tract of males increases in some way the maturation and performance of spermatozoa, favouring the storage and concentration 
of sperm. Probably, the ductus deferens is a site for sperm storage and maturation in snakes since the epididymis does not play a role in these functions as observed in mammals (Rojas et al. 2013).

The sexual segment of the kidney (SSK) is an accessory sexual structure that is present in male snakes and lizards
(Sever et al. 2012). This structure was characterized by a modification and hypertrophy of the epithelium lining the kidney ducts (Aldridge et al. 2011, Sever et al. 2012). The SSK was secretory when the testes were spermatogenically active and this secretion are mixed with the sperm forming part of the seminal fluid and was released into the female
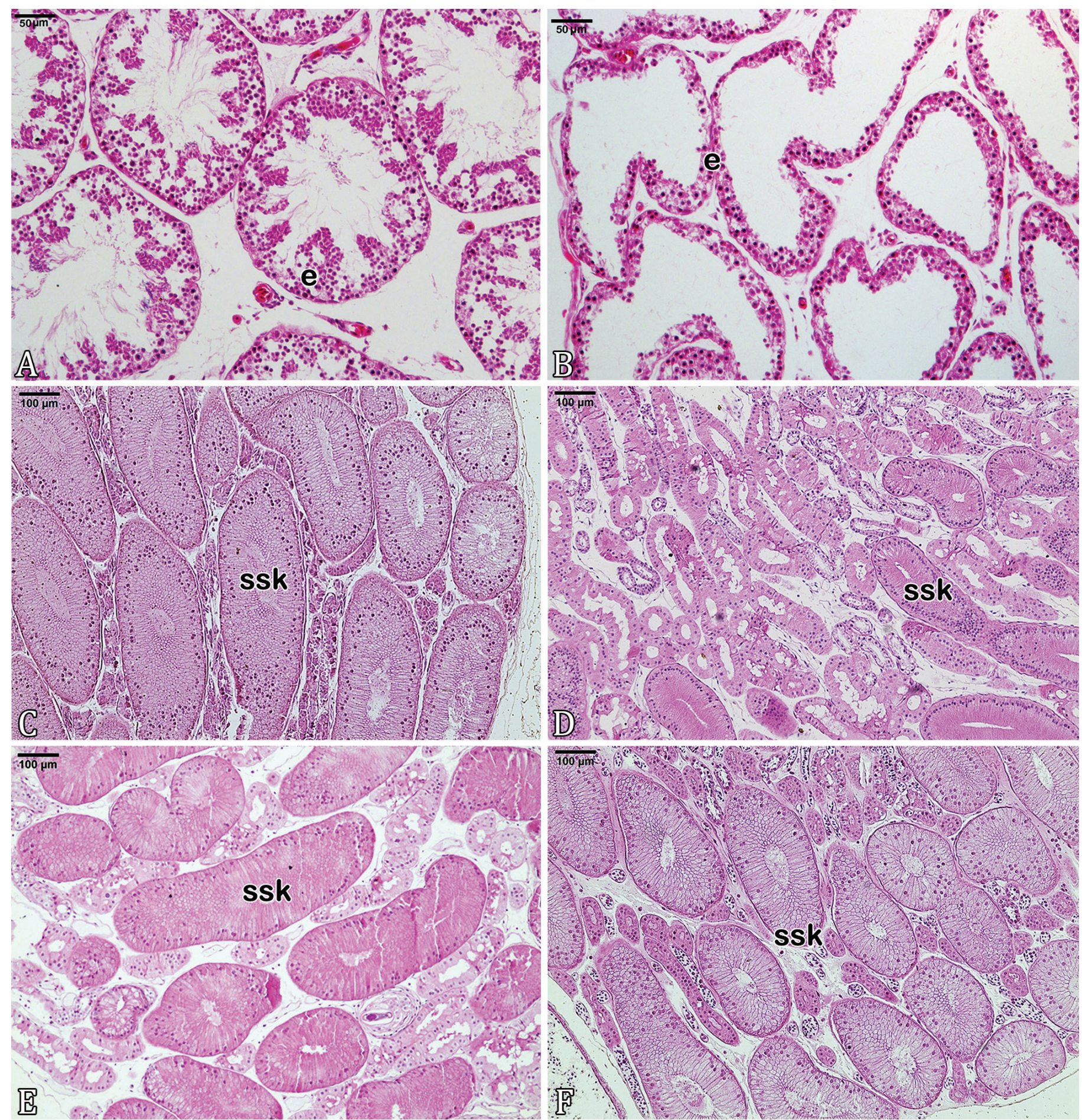

Fig.7. Transverse sections of the testis of Tomodon dorsatus during (A) summer and (B) winter. Note the difference between the tubular width and epitelial height of the seminiferous tubules. Tubules seminiferous epithelium (e). Transverse sections of the kidney of $T$. dorsatus during (C) spring, (D) summer, (E) autumn and (F) winter, showing the sexual segment of the kidney (ssk). (A-B) HE, bar = $50 \mu \mathrm{m}$. (C-F) HE, bar $=100 \mu \mathrm{m}$. 
genital tract during copulation (Prasad \& Reddy 1972, Sever et al. 2002, Sever \& Hopkins 2005, Melo et al. 2019). Although the SSK function in Squamata is still unknown (Sever et al. 2012), probably the SSK secretory product are involved with a copulatory plug formation (Devine 1975, Sever et al. 2002, Friesen et al. 2013), sperm activation (Bishop 1959), and/or seminal fluid production (Prasad \& Reddy 1972). A histological study showed the presence of granules scattered throughout the cytoplasm of the SSK epithelial cells (Baddi et al. 2018). These authors reported that the granules could be related to the cycle of SSK synthesis and secretion, besides the granules can be related to the spermatogenic cycle and mating activity. The presence of granules was not investigated in this study. Loebens et al. (2020) also had not cited the presence of granules in the SSK cells of T. dorsatus.

In this study, T. dorsatus presented a seasonal variation in SSK hypertrophy. The diameter of the SSK showed a peak in winter and spring, but there was no total regression during the other seasons. Similar feature was also observed in other species of snakes (Fox 1977, Aldridge \& Duvall 2002, Aldridge et al. 2009). The T. dorsatus from Brazilian south region also had an increased secretory activity of SSK in spring (Loebens et al. 2020). However, SSK regresses completely in the quiescence phase in the amphisbaenids and lizards
(Fox 1977). Sever et al. (2012) claimed that snakes undergo less seasonal variation in SSK hypertrophy than lizards. The SSK is androgen dependent, dependent on elevated plasma androgen levels (Krohmer et al. 2004). Aldridge et al. (2020) suggested that androgens from the interstitial cells of Leydig were responsible for development of the SSK. The SSK hypertrophy is related to the copulation period (Aldridge et al. 2009). In males of T. dorsatus, the hypertrophy occurs in winter and spring, corresponding to the mating period and fertilization (Bizerra 1998, Bizerra et al. 2005). In the lizard Eurolophosaurus nanuzae, the SSK activity also varied according to the seasonal reproductive cycle in synchrony with female reproductive seasonality (Melo et al. 2019).

In conclusion, although seasonal changes in SSK hypertrophy were observed, it was not possible to associate with the peak of spermiogenesis. Sperm storage occurred throughout the year, with no significant variation in the diameter of the ductus deferens in the austral seasons, which increases reproductive success of males and allows males of this species to mate in the period in which the females are receptive. Based on the macroscopic and microscopic findings of this study, probably the reproductive cycle of T. dorsatus, at the population level, can be characterized seasonal semi-synchronous, although there was testicular activity throughout the year with a
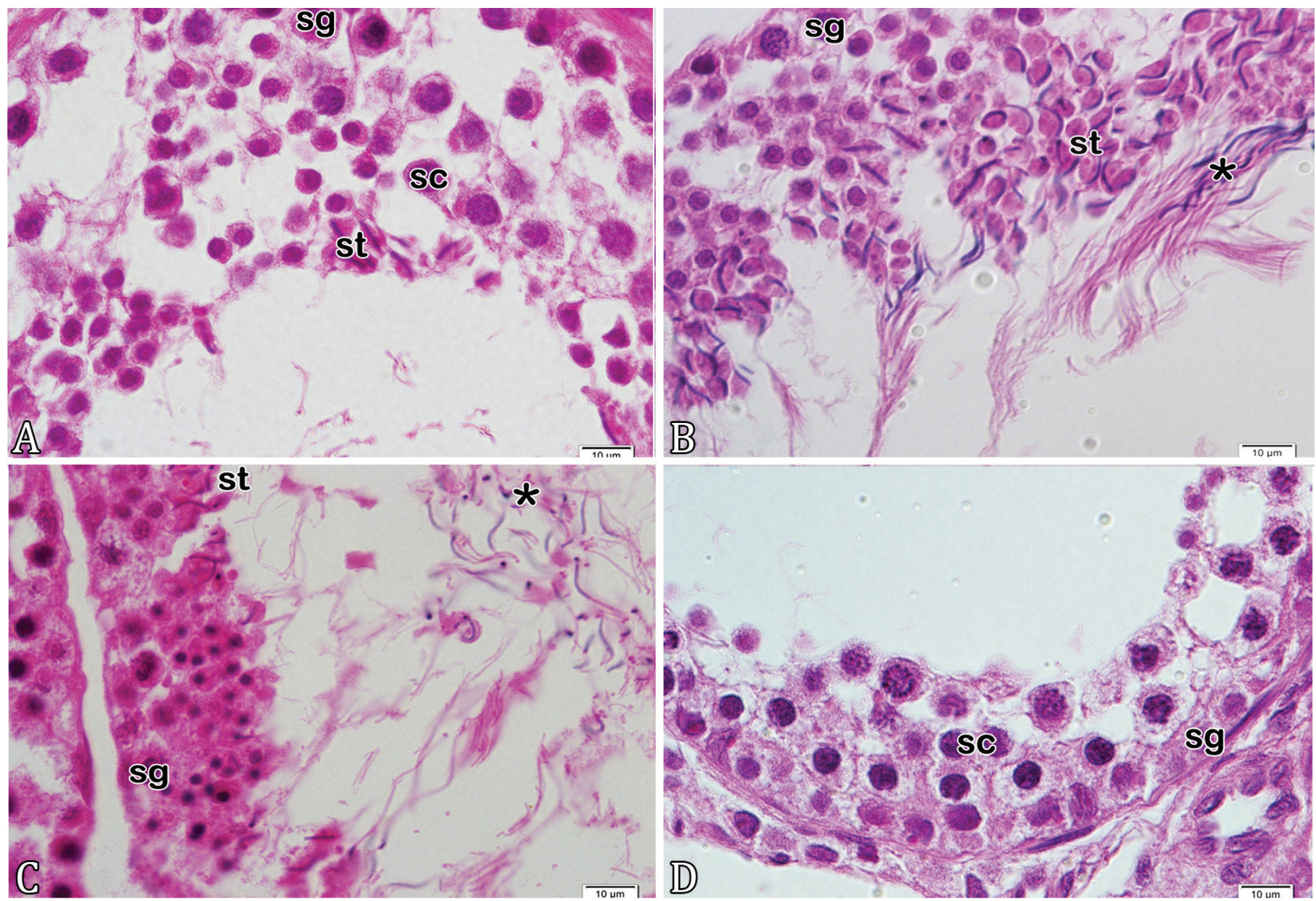

Fig.8. Transverse sections of the testis of Tomodon dorsatus showing the testicular stages. (A) Stage I (early recrudescence), (B) stage II (late recrudescence), (C) stage III (spermiogenesis), a great number of spermatozoa (asterisk) in the lumen, (D) stage V (late regression), no found spermatozoa in the lumen. Spermatogonias (sg), spermatocytes (sc), and spermatids (st). HE, bar $=10 \mu \mathrm{m}$. 


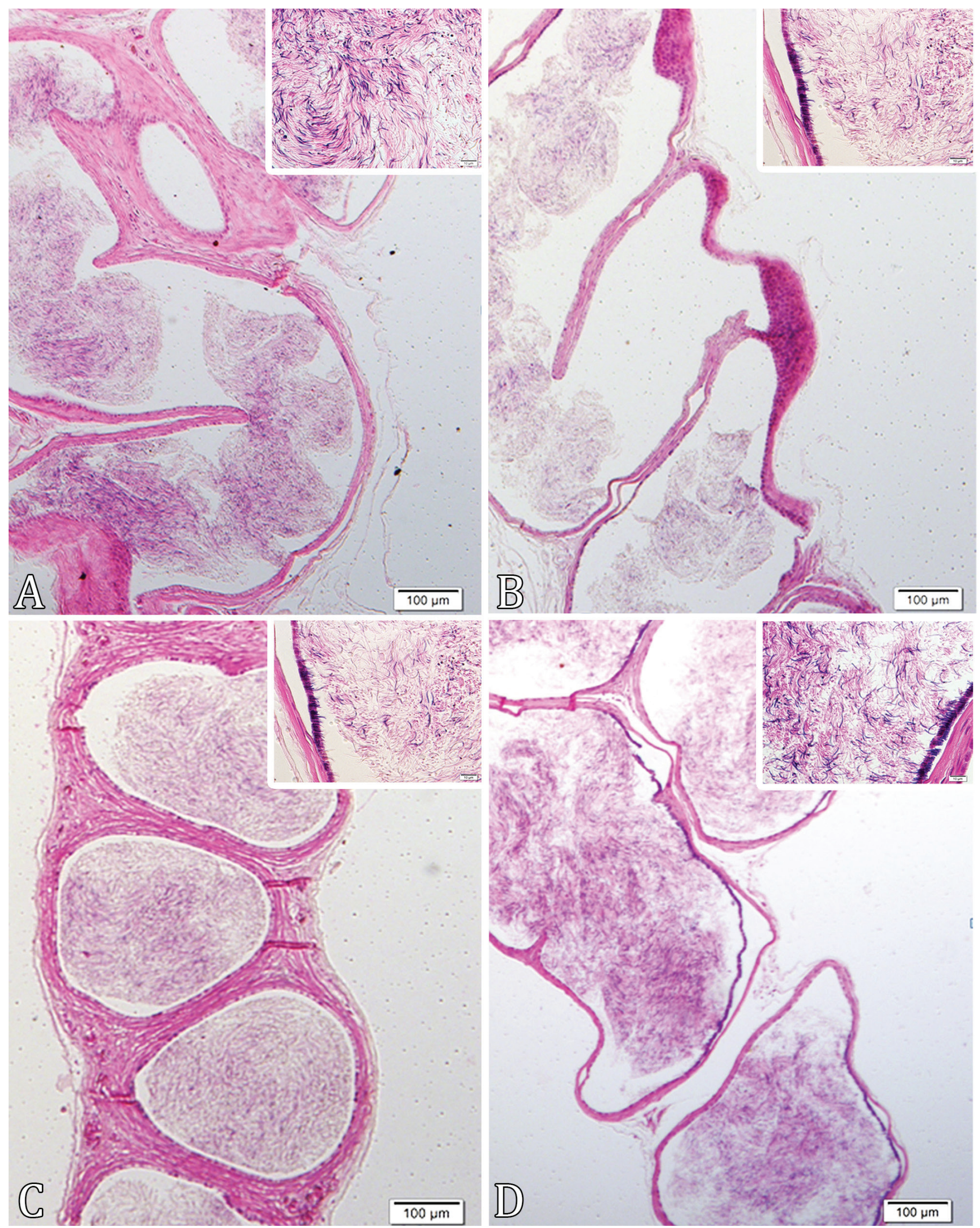

Fig. 9. Sections of the ductus deferens of Tomodon dorsatus showing spermatozoa in the lumen in (A) spring, (B) summer, (C) autumn, and (D) winter. Insets: note the spermatozoa in the high magnification of the sections. HE, bar $=100 \mu \mathrm{m}$. 
peak of spermiogenesis in summer; and at individual level, the reproductive cycle is discontinuous. This reproductive cycle is similar to described for T. dorsatus from Brazilian south region (Loebens et al. 2020). The findings of this study showed that the reproductive features found in T. dorsatus from the Southeastern region of Brazil were similar to those reported for this snake in the south of Brazil, suggesting that probably the reproductive traits can be conserved within tribe Tachymenini, even with some environmental differences such as the climate, since the climate of the southeast region is tropical (Rojas et al. 2013) and that of the south region is humid subtropical (Loebens et al. 2020).

Acknowledgments.- The authors would like to thanks "Instituto Butantan", São Paulo, Brazil, for providing the animals and for allowing access to the collection material and "Coordenação de Aperfeiçoamento de Pessoal de Nível Superior" (CAPES).

Conflict of interest statement.- The authors declared no potential conflicts of interest with respect to the research, authorship and/or publication of this article.

\section{REFERENCES}

Aldridge R.D. \& Duvall D. 2002. Evolution of the mating season in the pitvipers of North America. Herpetol. Monogr. 16:1-25. <https://dx.doi. org/10.1655/0733-1347(2002)016[0001:EOTMSI]2.0.CO;2>

Aldridge R.D., Goldberg S.R., Wisniewski S.S., Bufalino A.P. \& Dillman C.B. 2009. The reproductive cycle and estrus in the colubrid snakes of temperate North America. Contemp. Herpetol. 2009(4):1-31.

Aldridge R.D., Jellen B.C., Siegel D.S. \& Wisniewski S.S. 2011. The sexual segment of the kidney, p.477-509. In: Aldridge R.D. \& Sever D.M. (Eds), Reproductive Biology and Physiology of Snakes. CRC Press, Boca Raton, FL.

Aldridge R.D., Siegel D.S., Goldberg S.R. \& Pyron R.A. 2020. Seasonal timing of spermatogenesis and mating in Squamates: a reinterpretation. Copeia 108(2):231-264. <https://dx.doi.org/10.1643/CH-19-230>

Almeida-Santos S.M. \& Orsi A.M. 2002. Ciclo reprodutivo de Crotalus durissus e Bothrops jararaca (Serpentes, Viperidae): morfologia e função do oviduto. Revta Bras. Reprod. Anim. 26(2):109-112.

Almeida-Santos S.M., Braz H.B., Santos L.C., Sueiro L.R., Barros V.A., Rojas C.A. \& Kasperoviczus K.N. 2014. Biologia reprodutiva de serpentes: recomendações para a coleta e análise de dados. Herpetol. Bras. 3(1):14-24.

Almeida-Santos S.M., Laporta-Ferreira I.L., Antoniazzi M.M. \& Jared C. 2004. Sperm storage in males of the snake Crotalus durissus terrificus (Crotalinae: Viperidae) in Southeastern Brazil. Comp. Biochem. Physiol. 139(2):169174. <https://dx.doi.org/10.1016/j.cbpb.2004.08.004><PMid:15528165>

Baddi S.Y., Naik S.G., Jamuna K.V., Manjunatha K., Prasad R.V., Rajashailesha N.M. \& Ramkrishna V. 2018. Gross morphology of male genital organ and histomorphology of the renal sexual segment in the yellow rat snake (Elaphe obsolete quadrivittata). Indian J. Vet. Anat. 30(2):110-112.

Barros V.A., Sueiro L.R. \& Almeida-Santos S.M. 2012. Reproductive biology of the neotropical rattlesnake Crotalus durissus from northeastern Brazil: a test of phylogenetic conservatism of reproductive patterns. Herpetol. J. 22:97-104.

Bishop J.E. 1959. A histological and histochemical study of the kidney tubules of the common garter snake, Thamnophis sirtalis, with special reference to the sexual segment in males. J. Morphol. 104:307-357. <https://dx.doi. org/10.1002/jmor.1051040206> <PMid:13800985>

Bizerra A. 1998. História natural de Tomodon dorsatus (serpentes: Colubridae). Master's Thesis, Universidade de São Paulo, São Paulo. 79p.
Bizerra A., Marques O.A.V. \& Sazima I. 2005. Reproduction and feeding of the colubrid snake Tomodon dorsatus from Southeastern Brazil. Amphib. Reptil. 26(1):33-38. <https://dx.doi.org/10.1163/1568538053693350>

Brown G.P. \& Shine R. 2006. Why do most tropical animals reproduce seasonally? Testing hypotheses on an Australian snake. Ecology 87(1):133 143. <https://dx.doi.org/10.1890/04-1882> <PMid:16634304>

Citadini J.M. \& Navas C.A. 2013. Inter-individual variation and temperaturedependent antipredator behaviour in the snake Tomodon dorsatus (Dipsadidae). Behav. Processes 97:11-17.<https://dx.doi.org/10.1016/j. beproc.2013.03.008 > <PMid:23548560>

Costa H.C. \& Bérnils R.S. 2015. Répteis brasileiros: lista de espécies. Herpetol. Bras. 4(3):75-93.

Devine M.C. 1975. Copulatory plugs in snakes: enforced chastity. Science 187(4179):844-845. <https://dx.doi.org/10.1126/science.1114329> $<$ PMid:1114329>

Foesten M.H., Tozetti A.M. \& Henkes J.A. 2017. Avaliação do nível de conhecimento da ofidiofauna por moradores rurais do Vale do Rio dos Sinos, sul do Brasil. Revta Gest. Sust. Amb., Florianópolis, 5(2):175-199. <https://dx.doi.org/10.19177/rgsa.v5e22016175-199>

Fox H. 1977. The urogenital system of reptiles, p.1-157. In: Gans C. \& Parsons T.S. (Eds), Biology Reptilia. Academic Press, New York.

Fox W. 1956. Seminal receptacles of snakes. Anat. Rec. 124(3):519-539. <https://dx.doi.org/10.1002/ar.1091240303> <PMid:13314111>

Friesen C.R., Shine R., Krohmer R.W. \& Mason R.T. 2013. Not just a chastity belt: the functional significance of mating plugs in garter snakes, revisited. Biol.J. Linn.Soc. 109(4):893-907. <https://dx.doi.org/10.1111/bij.12089>

Girons H.S. 1982. Reproductive cycles of male snakes and their relationship with climate and female reproductive cycles. Herpetologica 38(1):5-16.

Gribbins K.M., Happ C.S. \& Sever D.M. 2005. Ultrastructure of the reproductive system of the black swamp snake (Seminatrix pygaea). V. The temporal germ cell development strategy of the testis. Acta Zool. 86(4):223-230. <https://dx.doi.org/10.1111/j.1463-6395.2005.00201.x>

Krohmer R.W., Martinez D. \& Mason R.T. 2004. Development of the renal sexual segment in immature snakes: Effect of sex steroid hormones. Comp. Biochem. Physiol. 139(1):55-64. <https://dx.doi.org/10.1016/j. cbpb.2004.06.015><PMid:15471681>

Loebens L., Almeida-Santos S.M. \& Cechin S.Z. 2020. Reproductive biology of the sword snake Tomodon dorsatus (Serpentes: Dipsadidae) in South Brazil: comparison within the tribe Tachymenini. Amphibia-Reptilia 41(4):445-459. <https://dx.doi.org/10.1163/15685381-bja10012>

Loebens L., Hendges C.D., Almeida-Santos S.M. \& Cechin S.Z. 2019. Morphological variation and sexual dimorphism in two sympatric dipsadine snakes from Southern Brazil. Zool. Anz. 280:42-51. <https://dx.doi.org/10.1016/j. jcz.2019.03.004>

Loebens L., Rojas C.A., Almeida-Santos S.M. \& Cechin S.Z. 2017. Reproductive biology of Philodryas patagoniensis (Snakes: Dipsadidae) in South Brazil: female reproductive cycle. Acta Zool. 99(2):105-114. <https://dx.doi. org/10.1111/azo.12200>

Marques O.A.V. \& Sazima I. 2004. História natural dos répteis da Estação Ecológica Juréia-Itatins, p.257-277. In: Marques O.A.V. \& Duleba W. (Eds), Estação Ecológica Juréia-Itatins: ambiente físico, flora e fauna. Holos, São Paulo.

Mathies T. 2011. Reproductive cycles of tropical snakes, p.511-550. In: Aldridge R.D. \& Sever D.M. (Eds), Reproductive Biology and Phylogeny of Snakes. Science Publisher, New Hampshire.

Melo G.C., Nascimento L.B. \& Galdino C.A.B. 2019. Lizard reproductive biology beyond the gonads: an investigation of sperm storage structures and renal sexual segments. Zoology 135:125690. <https://dx.doi.org/10.1016/j. zool.2019.05.002><PMid:31383295> 
Pizzato L., Cantor M., Oliveira J.L., Marques O.A.V., Capovilla V. \& Martins M. 2008. Reproductive ecology of Dipsadine snakes, with emphasis on south american species. Herpetologica 64(2):168-179. <https://dx.doi. org/10.1655/07-031.1>

Pleguezuelos J.M. \& Feriche M. 1999. Reproductive ecology of the horseshoe whip snake, Coluber hippocrepis, in the southeast of the Iberian Peninsula. J. Herpetol. 33(2):202-207. <https://dx.doi.org/10.2307/1565715>

Prasad M.R.N. \& Reddy P.R.K. 1972. Physiology of the sexual segment of the kidney in reptiles. Gen. Comp. Endocrinol. 3(Supl.):649-662. <https:// dx.doi.org/10.1016/0016-6480(72)90196-7>

Quintela F.M., Marques W.C. \& Loebmann D. 2017. Reproductive biology of the green ground snake Erythrolamprus poecilogyrus sublineatus (Serpentes: Dipsadidae) in subtropical Brazil. An. Acad. Bras. Ciênc. 89(3):2189-2197. <https://dx.doi.org/10.1590/0001-376520160805>

Rojas C.A. 2009. Modulação fisiológica do ciclo reprodutivo, comportamento sexual e atividade sazonal em Sibynomorphus mikanii e Sybynomorphus neuwiedi (dormideira). Master's Thesis, Universidade de São Paulo, São Paulo. 85p.

Rojas C.A., Barros V.A. \& Almeida-Santos S.M. 2013. The reproductive cycle of the male sleep snake Sibynomorphus mikanii (Schlegel, 1837) from southeastern Brazil. J. Morphol. 274(2):215-228. <https://dx.doi. org/10.1002/jmor.20099><PMid:23192800>

Santos J.L. 2019. Variação sexual no desempenho locomotor e metabolismo de Tomodon dorsatus (Serpentes: Dipsadidae). Master's Thesis, Universidade Federal de São Paulo, Diadema. 59p.

Schuett G.W. 1992. Is long-term sperm storage an important component of the reproductive biology of temperature pitvipers? Biol. Pitvipers 12:169-184.

Schuett G.W., Carlisle S.L., Holycross A.T., O'Leile J.K., Hardy D.L., Van Kirk E.A. \& Murdoch W.J. 2002. Mating system of male Mojave rattlesnakes
(Crotalus scutulatus): seasonal timing of mating, agonistic behaviour, spermatogenesis, sexual segment of the kidney, and plasma sex steroids, p.515-532. In: Schuett G.W., Höggren M., Douglas M.E. \& Greene H.W. (Eds), Biology of the Vipers. Eagle Mountain, Carmel, Indiana.

Sever D.M. \& Hopkins W.A. 2005. Renal sexual segment of the ground skink, Scincella laterale (Reptilia, Squamata, Scincidae). J. Morphol. 266(1):46-59. <https://dx.doi.org/10.1002/jmor.10364> <PMid:16121401>

Sever D.M., Rheubert J.L., Gautreaux J., Hill T.G. \& Freeborn L.R. 2012. Observations on the sexual segment of the kidney of snakes with emphasis on ultrastructure in the yellow-bellied sea snake, Pelamis platurus. Anat. Rec. 295(5):872-885. <https://dx.doi.org/10.1002/ar.22435><PMid:22396145>

Sever D.M., Stevens R.A., Ryan T.J. \& Hamlett W.C. 2002. Ultrastructure of the reproductive system of the Black swamp snake (Seminatrix pygaea). III. Sexual segment of the male kidney. J. Morphol. 252(3):238-254. <https:// dx.doi.org/10.1002/jmor.1102>

Siegel D.S., Sever D.M., Rheubert J.L. \& Gribbins K.M. 2009. Reproductive biology of Agkistrodon piscivorus lacepede (Squamata, Serpentes, Viperidae, Crotalinae). Herpetol. Monogr. 23(1):74-107. <https://dx.doi. org/10.1655/08-031.1>

Sivan J., Panzera A. \& Maneyro R. 2016. Male reproductive cycle of a neotropical snake, Lygophis anomalus (Dipsadidae), in a temperate geographic distribution. S. Am. J. Herpetol. 11(2):114-118. <https://dx.doi. org/10.2994/SAJH-D-15-00021.1>

Stanley T.E. \& Sever D.M. 2011. Male urogenital ducts and cloacal anatomy, p.502-541. In: Aldridge R.D. \& Sever D.M. (Eds), Reproductive Biology and Phylogeny of Snakes. Science Publishers, New Hampshire.

Tsai T.S. \& Tu M-.C. 2000. Reproductive cycle of male chinese green tree vipers, Trimeresurus s. stejnegeri, in northern Taiwan. J. Herpetol. 34(3):424-430. <https://dx.doi.org/10.2307/1565366> 